\title{
CONCEPT OF TAQRIBRA'YAI (BRIDGING TWO VIEWS) IN BID'AH POLEMIC WITHIN THE MALAY MUSLIM SOCIETY
}

\author{
Firdaus Khairi Abdul Kadir ${ }^{*}$, Hailan Salamun ${ }^{2}$, Asyraf Hj Ab. Rahman ${ }^{3}$, Fakhratu Naimah Muhad ${ }^{4}$ \\ ${ }^{1,2,3}$ Nationhood and Civilization Department, Universiti Malaysia Terengganu, Malaysia, ${ }^{4}$ Research Institute of Islamic \\ Products and Malay Civilization, Universiti Sultan Zainal Abidin, Malaysia. \\ Email: ${ }^{1 *}$ firdauskhairi@umt.edu.my, ${ }^{2}$ hailan@umt.edu.my, ${ }^{3}$ asyraf@umt.edu.my, ${ }^{4}$ naimahmuhad@icloud.com
} Article History: Received on $15^{\text {th }}$ October 2019, Revised on $27^{\text {th }}$ March 2020, Published on $12^{\text {th }}$ April 2020

\begin{abstract}
Purpose of the study: In general, term bid'ah is easily understood by majority Muslims of the Muslim World including those in the Malay Archipelago. The views often debated in regards to bid'ah revolve around issues of new practice that considered as bid'ah or bid'ah hasanah. This study tried to bridge the two views pioneered by Imam Shafie (150204AH) and Imam Shatibi (720-790AH). At the end, this study may contribute to reconcile the disputation and arguments within Malay Muslim society.
\end{abstract}

Methodology: This study was mainly opting the information gathered from Islamic religious books as well as academic journals that discuss the issues of bid'ah. Other than that, this research also referred to both primary sources of al-Quran and Sunnah al Hadith to support the arguments. The related data was accumulated by using the content analyses approach and divided into several themes.

Main Findings: The findings of this study show that the phrase of 'all bid'ah is deviant' is strongly affecting the status of other good practices as deviant or can be classified as good invention or bid'ah hasanah. In this study, to solve this polemics, it is suggested to opt the concept of taqrib ra'yai by using two of Usul al-Fiqh methods.

Applications of this study: Islamic study, especially in the field of Usuluddin and history of Islam in Malay Archipelago and its movement. This study needs to benefitted the whole Muslim community by spreading the importance of bridging these two views either through verbal or written form. By that, the Muslim community, especially amongst Malaysians able to get clarification and solve the disputed issues, especially regarding the bid'ah hasanah.

Novelty/Originality of this study: The study suggested Taqrib Ra'yai (bridging two views) method which is intended to bridge the gap of the disputes among the Mujtahid leaders (persons who has been certified and acknowledged as capable of interpreting religious law) as well as among the other Muslims.

Keywords: Taqrib Ra'yai, Bid'ah, Practice, Heresy, Islamic Understanding.

\section{INTRODUCTION}

Bid'ah derived from the word bada' (بدع) which means initiating something without any precedent. For example, anyone who created and started something that led to an event or thing to happen, like the existence of heaven and earth (alKuwaiti, 2008). In the terminology of the Shariah or Islamic law, bid'ah means something that has been introduced into the religion of Allah that has no general or specific basis to support it. The term bid'ah began to be known among the Muslims based on the hadith of the Prophet, narrated by Irbadh bin Sariah. In the Hadith, the Prophet (pbuh) instructed his companions to be careful of new things in religion that would initiate bid'ah. The Prophet (pbuh) further reminded that all new practices are considered bid'ah, all bid'ah are astray and those who astray belong in hell. For that reason, the scholars had been debating on the true meaning behind the Prophet's statement and polemics in some of the religious practices such as tahlil, talqin and other religious ritual that have no specific basis but were said to be derived from the interpretation of the hadith.

The interpretation of hadith is having a different view and historical chronology to the development of Quranic tafsir. Many of the exegesis of Quranic verses are generally used for the purpose of finding the solution to the problems amongst the current Muslim Ummah (Rahman, Kadir, \& Adam, 2017). Meanwhile, the matters related to the bid'ah are relatively coupled with the new practices instead of handling the ummah's conflicts.

This study aims to bridge the gap between disputed issues among religious groups and followers by bridging the two views of accepting bid'ah hasanah. Researchers are strongly advised that the fight should be avoided in order to prevent disintegration among Muslims. Despite the existing disputes to some extents, the attempt to bridge the gap through Taqrib Ra'yai (bridging two views) concept seems to be capable of easing the tensions that occur in Muslim society particularly in Malay Muslim contexts (Anshari, 2018). The Malay Muslim community are known for their belief in Islam and follow Islamic teachings introduced by traders and Muslim scholars arriving from Arabia, China and the Indian subcontinent. In addition to this teaching, there are some practices which become the point of dispute within Muslims community in particular, those amongst layman who does not have a detailed knowledge of a particular subject. The dispute revolves around some practices which have been practiced for a long time in the Malay community, for example, reading surah Yasin on Friday night, organizing Tahlil ceremony after death and reading the talqin close to the grave after the funeral. These practices are considered contradictory to the Prophet's teachings and thus should be 
stopped. From this, there is a conflict between two streams of understanding which requires the best approach to prevent the Muslims in this region to be divisive. In order to prevent the occurrence of disputes in society, a new approach is proposed to bridge the gap between the disputes thus making Muslim living harmoniously and understand each other in regards to religious matters. Qutb (2015) once, wrote on calling Muslim to return back to their basic teaching prescribed in the Quran in his Fi Zilal al-Quran (2:777) stating that: "with the passing of generation after generation after the miracle period (the prophet's period), many libraries began to be filled with books on jurisprudence and law...many leaders started to speak about justice, many tongues started to talk about its application....there were various theories, means and plans suggesting its full application but the only true means of realizing justice in human conscience and life is from within that manhaj of Allah' (Asyraf,, 2012).

Hence, this kind of discussion extends to the existence of the term bid'ah hasanah which loosely translated as a good invention. Bid'ah hasanah received a huge refutation and disputation from Muslim scholars due to the phrase of 'all bid'ah is dhalalah (deviant). The presence of bid'ah hasanah was pioneered by Imam Shafi'ie and reciprocated by few prominent scholars such as al-Qadhi, al-Ghazali, Ibnu al-Arabi, Ibnu Hajar and others. In brief, al-Shafie'ie explained that bid'ah hasanah is any practices that are not contradict to al-Quran and Sunnah. Nonetheless, he had not extended the discussion further (Anshari, 2018).

\section{METHODOLOGY}

This study opted the content analysis approach by studying the disputed issues and terminologies related to the bid'ah practices. Hence this research was primarily benefitting the information from the secondary sources such as religious books and articles by Muslim scholars by analysing them according to the main themes of the study. Amongst the example of the discussed themes are the existence of the bid'ah hasanah and the meaning of taqrib al-ra'yain. In addition, some Quranic verses and the prophet's hadith are also mentioned to support any necessary arguments as discussed in the study.

\section{DISCUSSION AND ANALYSIS}

In highlighting the study of the bid'ah from the perspective of syari'ah, it was found that the ulama had disputed on views whether bid'ah hasanah exist or does not exist.

\section{Bid'ah Hasanah does not exist}

Scholars who supported this opinion stated that all bad practices are bid'ah. Therefore, the scholars who adhere to this view argued by considering that the bid'ah term symbolizes sinfulness, thus bid'ah hasanah should not be associated with the matter of religious obligation. If a new action exists for the better development of Islam, it should be termed Istihsan, Masalih Mursalah and so on but not bid'ah hasanah. Using the latter term may lead to confusion amongst Muslims. Among the ulama who hold this view are Imām Mālik (164 H-241H), al-Shātibī (790 H) and Ibn Taimiyyah $(728 \mathrm{H})$. They believe that the word kullu in the hadith narrated by Irbadh bin Sariyah is a common expression which means all including matters related to religion. Therefore, bid'ah should not be devoted to certain aspects only. This argument is based on Imam al-Shāțibī's opinion in his book al-I'tisam. (al-Qaradawi, 2008).

Some scholars such as Imām Mālik, Imam al-Shāṭibī and Ibn Taimiyyah argue that all bid'ah are ḍalālah (astray), whether it appears in the context of custom, worship or creed. In explaining this opinion, Imam al-Shāțibī stated,

"Bid'ah is a way in the creation of a religion that conflicts with syarak. Bid'ah also aims in making bid'ah practice as shara 'practice. However, the fact is the practice is not what Shara requires. This definition covers all aspects of faith, worship and custom. To illustrate, fasting vows while standing and exposed under a blazing (unprotected) sun, allocating food and clothing for a certain group only, disregarding other groups without reasonable cause "( $\underline{\text { al-Kuwaiti, }}$ 2008).

\section{Existence of Bid'ah Hasanah}

The second opinion considers bid'ah hasanah indeed exists. Scholars supporting this perspective include Al-'Izzu al-Din bin Abdul Salam (577 H-660H), Imām al-Nawāwi (631 H-676 H) and Ibn Jauzi (510H-597H). This group follows Imām Al-Shafi'i's opinion $(150 \mathrm{H}-204 \mathrm{H})$ in relation to bid'ah, stating:

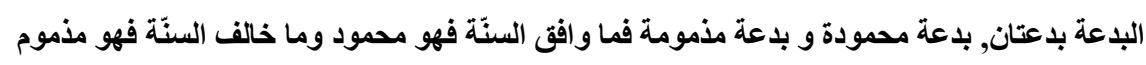

The Bid'ah consists of two conditions, the good heresy and heretical heresy. Anything that meets the requirements of alSunnah is a good bida'ah, while things contrary to al-Sunnah are the heresy innovations. (Ibrahim, 1997).

Some scholars such as Imām Al-Shafi'i, Imam Qurafi, Imām al-Nawāwi and Imam Ibn Hajar believe that the bid'ah in the hadith of Rasulullah SAW is not too general. The term needs to be clarified and specified according to certain conditions or situations. This means, bid'ah practice can be divided into two situations whereby a practice that has the basis of syariah is considered bida'ah hasanah, while practices that do not have the basis of religious justification and ignorance are considered bid'ah dalālah (Ramli, 2005; Adam, et al., 2017). Following this understanding, Imām AlShafi'i (r.a) was on a view that any new matters relating to Islamic practices are divided into two conditions; i) new 
practices introduced, but contrary to the Quran, al-Sunnah, al-Athār and al-Ijma ' are categorized as ḍalālah (misguided) and ii) new practices introduced, made of goodness but do not contradictory to the Quran, al-Sunnah and ijma' are categorized as hasanah (Ramli, 2005)

Among the supporters or proponents of this view is Al-'Izzu bin Abdul Salam (577H-660H). In his book Qawaid alAhkam, he stated that the establishment of the bid'ah law should be based on five legal structures, namely; a) the obligatory (study the knowledge of Nahu); b) unlawful (the deviation of the creed); c) circumcision (such as Maslahah Ammah /common interest), d) makruh such as carving in mosques and e) must (choices in fancy food, drink and clothing) (

The findings of the study reveal that Muslims need to return to the essential Islamic teachings. The following discussions propose Taqrib Ra'yain approach in dealing with the disputed issues among Muslims in particular that related to the question of bid'ah.

\section{Taqrib Ra'yain Approach}

In this study, the proposed Taqrib Ra'yain is intended to bridge the gap of disputes between two different opinions. Both views can be adopted by all Muslims. The first view has its own argument, likewise the second view is also acceptable and appropriate to be followed by Muslims in the Malay Archipelago. It is worth noting from the language perspective that hasanah or al-birr means goodness. Having said that, the definition of hasanah is synonymous with the word al-birr in the Qur'an. From the aspect of terminology, kindness means full obedience and good deeds, aiming to bring oneself closer to God and the act is accepted by Him. On this ground, it can be concluded that al-birr is all the good deeds that do not contradict Allah's command (Mamat, 1989). Therefore, all acts of good which do not contrary to God's command, are judged as al-birr. The practice is therefore acceptable and permissible by religious teachings.

Accordingly, Muslims need to return to the method of Usul al-Fiqh to understand the current environment. What is meant by reverting to the Usul al-Fiqh method is that the Muslim scholars should study some cases that exist in the archipelago based on the current environment. This leads the science of fiqh to continue to flourish without leaving the roots of Islamic law. For example, the existence of the Islamic financial system, halal food and bio-medical systems need to be carefully examined by returning to the Usul al-Figh as a solution (Mahmood Zuhdi, 2010). In the context of this study, Taqrib Ra'yain approach (narrowing the gap of the dispute) is proposed based on two (2) methods of Usul alFiqh:

i- الأمور بمقاصدها (Matters shall be judged by their objectives)

The emergence of this method is based on the prophet Rasulullah SAW stating;

إنما الأعمال بالنيّات وإنما لكل امرئ ما نوى فمن كانت هجرته إلى الله ورسوله فهجرته الى الله ورسوله ومن كانت هجرته لانيا يصيبها أو امرأة ينكها فهجرته إلى ما هاجر إليه.

Every practice starts with intentions. And indeed, everything depends on what is intended. Whoever migrates because of Allah and His Messenger, then the (hijrah) migration is accepted by Allah and His Messenger. But, whoever migrates because of the world, he will get the world, if because of a woman, he will be able to marry the woman. Indeed, the migration is dependent on what is migrated.

In the Malay community context, there are some practices carried out with pure intentions. Among them is the practice of Talqin or known as Talqin al-mayyit consists in some phrases regarding Islamic beliefs that are recited for the deceased before burying his or her corpse. The practice is performed at the cemetery and heard by most families and friends of the deceased. Although such practice has never been done by the Prophet, the actual intention of Talqin is to advice and instil fear in the heart and revive hearts after they had been (spiritually) dead; it will fill them with love of Allah, the desire to seek His blessings. Thus, it is reasonable that the practice is considered as bida'ah hasanah according to the second perspective or judged as al-birr (the element of goodness) in the context of the first perspective.

ii- العادة محكّمة (Cultural usage shall have the weight of law).

This method is based on Ibn Mas'ud's expression (r.a),

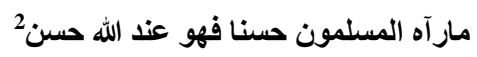

Meaning: What Muslims view as good, is good in the sight of Allah.

In the view of Prophet's companions, the situation and surrounding environment should be taken into consideration before setting any law. As such, in the context of the ijab and qabul during the purchasing and selling process for instance, Muslim scholars needs to take into account the habits and practices (not contrary to Quranic and hadith

\footnotetext{
${ }^{1}$ Hadith from Umar bin al-Khattab RA, according to al-Albani, this hadith was narrated by Abu Dawud and was issued from Sahih Abu Dawud. No hadith: 2201. The conclusion of this hadith is Sahih. According to Ibn Taymiyyah, in his book Majmu 'al-Fatawa, No Hadith 20/223, this hadith is Sahih.

${ }^{2}$ Ibnu Jauzi in al-Wahiyat, no. 452, stated this expression is from Ibn Mas'ud (r.a) 
injunctions) spread in the local community before deciding whether a transaction is valid or null. Considering the Usul al-Fiqh method, any practice that becomes a habit in a society should be highlighted in setting any law. For example, the practice of Tahlil, Talqin and Yasin recitation on Friday night has become a routine practice for Muslims in the region. Although the practice was never performed by the Prophet, but the practice was able to instil religious awareness amongst Muslims thus, considered permissible (Saleh, t.t). Henceforth, the practice can be categorised as bid'ah hasanah according to the second perspective or judged as the concept of al-birr (good element) in the first perspective. In this case, it can be concluded that customary practices such as tahlil, talqin and Yasin reading on Friday night are evaluated as a branch of public worship just like other everyday work that is carried out with full dedication and trust, as long as the practice does not mix with the immoral and superstitious elements (Rahman et al., 2017). Besides, these practices are able to maintain the feeling of self-humility towards Allah and guarding the Muslims from falling into the quagmire of treason (Omar, Adam, Baru, \& Norhashimah, 2017).

\section{CONCLUSION}

The term bid'ah revolve around issues of new practice that considered as bid'ah or bid'ah hasanah. This study stated the two views pioneered by Imam Shafie and Imam Shatibiy. Concurrently, the study also suggested Taqrib Ra'yai method which is intended to bridge the gap of the disputes among the mujtahid leaders as well as among the Muslims. In the Malay community context, there are some practices carried out with pure intentions. Among them is the practice of Talqin or known as Talqin al-mayyit consists in some phrases regarding Islamic beliefs that are recited for the deceased before burying his or her corpse. Although such practice has never been done by the Prophet, the actual intention of Talqin is to advice and instil fear and strong belief in Allah, thus considered as bida'ah hasanah.

In the view of Prophet's companions, the situation and surrounding environment should also be taken into consideration before setting any law. As such, Muslim scholars needs to take into account the habits and practices (not contrary to Quranis and hadith injunctions) spread in the local community before deciding whether a transaction is valid or null. Considering the Usul al-Fiqh approach, any practice that becomes a habit in a society should be highlighted in setting any law. For example, the practice of Tahlil, Talqin and Yasin recitation on Friday night that become a routine practice for Muslims in the region. Although the practice was never performed by the Prophet, but the practice was able to instil religious awareness amongst Muslims thus, considered permissible.

Considering the above polemics, al-Qaradawi's view should be taken into account when he stressed that there are alBid'ah al-Mughallazhah (a very heavy Bid'ah) as practiced by Shi'i, the flow of mysticism and the like that deviates from the basis of Islamic religion (Islamic Akidah), and al-Bid'ah al-Khafifah (light Bid'ah). This innovative bid'ah though in contradiction to some Ijtihäd but is still in the context of Islamic law and permissible if such practice did not leading disintegration amongst Muslims (al-Qaradawi, 1995).

\section{LIMITATION AND FUTURE STUDY}

This study limited to the context and scenario within Malay Muslim community in Malaysia only. For future research, it will be focussing on the assured practices on its genuine status of its practicality by Prophet Muhammad. Hence, the Syariah of Islam able to be guaranteed and practiced by all Muslims especially in Malaysia.

\section{IMPLICATIONS OF THE STUDY}

By understanding the purpose of this study in bridging these two views, it may help the Muslim community to stay in a good ambience, particularly amongst Malaysians. The common practices such as talqin and tahlil able to be practiced as long as their understanding on the concept of bid'ah is clear and understood by the whole Muslim community.

\section{ACKNOWLEDGEMENT}

This study was supported by Universiti Malaysia Terengganu (UMT) and Universiti Sultan Zainal Abidin (UniSZA), Terengganu, Malaysia. We thank our colleagues from Center for Fundamental and Liberal Education, UMT and Research Institute for Islamic Products and Malay Civilization, UniSZA who provided comments, enlightenment and expertise that significantly assisted this research, although they may not agree with all of the discussions and conclusion of this research.

\section{REFERENCES}

1. Adam, F., Khairi, F., Kadir, A., Hadzrullathfi, S., Omar, S., Yusoff, Z., \& Hishamudin, W. (2017). Heretical Innovation of Distorted Beliefs (Bid'ah Dalalah) and Superstitious Practices Among Muslim Society in Malaysia. Asian Social Science, 11(24), 147-152. https://doi.org/10.5539/ass.v11n24p147

2. Abidin, M. A. (2005). Bid'ah Hasanah: Istilah Yang Disalah Fahami. Johor Bahru: Perniagaan Jahabersa.

3. al-Arab, J. m.-L. (1988). al-Mu'jam al-Arabi al-Asasi. Tunisia: Jamiah al-Dual al-Arabiyyah.

4. al-Hasani, A.-S. M.-M. (1999). Mafhum al-Salaf fi Fahmi al-Nusus baina Nadzariah wa Tadhbiq. Beirut, Lubnan: Maktabah al-Asriyyah.

5. al-Kuwaiti, M. F. (2008). Bid'ah: Kupasan Berdasarkan Ensiklopedia Fekah. Kuala Terengganu: Majlis Agama Islam Dan Adat Melayu Terengganu (MAIDAM). 
6. Al-Nuwawi, M. Y. (1995). Al-Arbauun al-Nuwawi wa Syarhiha. Mansourah, Mesir: Dar al-Khulafa'.

7. al-Qaradawi, Y. (1995). Fi Fiqh Al-Aulawiyyat wa Dirasatu alJadidah fi Dhau' al-Quran wa Sunnah. Qaherah, Mesir: Maktabah Wahbah.

8. al-Qaradawi, Y. (2001). Al-Fiqh Al-Islami Baina Al-Asalah wa Al-Tajdid. Beirut: Muassasah al-Risalah.

9. al-Qaradawi, Y. (2008). Al-Sunnah wa al-Bid'ah. Qaherah,Mesir: Maktabah Wahbah.

10. al-Shatibi, A. I. (1992). Al-I'tisom. Al-I'lanat al-Syarqiyyah.

11. al-Suyuti, J. A. (1990). Al-Asybah wa al-Nadhair. Beirut: Darul Kutub Al-Ilmiyyah.

12. Anshari, Z. (2018). KONSEP BID'AH HASANAH (Perpspektif Maqashid Al-Syathibi dan Ibnu 'Asyur). Ilmu Ushuluddin, 17(1), 30-43.

13. az-Zuhaily, W. (1991). Tafsir Munir Juzuk-1. Beirut: Darul Fikir.

14. Basmeih, A. b. (1987). Tafsir Pimpinan Al-Rahman. Kuala Lumpur: Jabatan Perdana Menteri.

15. Firdaus. (2007). Kedudukan Al-Qawaid Al-Fiqhiyyah Dalam Penetapan Hukum. Hadharah (Jurnal Keislaman dan Peradaban),IAIN,Imam Bonjol, Padang, Indonesia, 23-45.

16. Ibrahim, B. (1997). Khilafiyyah, Bid'ah \& Maslahah Umum. Kuala Lumpur: Darul Nu'man.

17. Majid, M. Z. (2010). Mazhab Shafie Di Malaysia: Masalah Dan Kerangka Penyelesaian. Kuala Terengganu: Penerbitan Yayasan Islam Terengganu.

18. Mamat, C. Y. (1989). Konsep al-Birr Mengikut Al-Quran. Jurnal Islamiyyat UKM, 43-52.

19. Mas'od, M. A. (2007). Bid'ah: Antara Dua Pendekatan. Jurnal Penyelidikan Islam, JAKIM, bil 20, 23-43.

20. Omar, S. H. S., Adam, F., Baru, R., \& Norhashimah, Y. (2017). Tok Ku Paloh's Manual on Sufi Practices in Ma'arij Al-Lahfan Li Al-Taraqqi Ila Haqaiq Al-'irfan. Social Science and Humanities. 25, 1-12.

21. Rahman, A. H. A., Kadir, F. K. A., \& Adam, F. (2017). The Development of Tafsir from the Time of the Prophet Muhammad (PBUH) Down to Ibn Kathir. Medwell Journals, 12(7), 1184-1190.

22. Ramli, R. (2005). Persoalan Bid'ah Dalam Beribadah Dalam Konteks Penghayatan Islam Di Malaysia. Jurnal Syariah Jilid 13, Bil 2 (Jun-Disember), 17-46.

23. Salam, A.-I. b. (1999). Qawaid al-Ahkam. Beirut: Darul Kutub Ilmiyyah.

24. Saleh, H. (t.t). Qawaed al-Fiqhiyyah. Kota Bharu: Pustaka Aman Press. 